\title{
PROJECTS IN FOUNDATIONS AND REGISTERED ASSOCIATIONS OF THE NON-GOVERNMENTAL ORGANIZATIONS SECTOR IN POLAND
}

\author{
Paulina MAJOR \\ Silesian University of Technology, Faculty of Organization and Management, Institute of Economics and \\ Informatics, Zabrze; paulina.major@polsl.pl, ORCID: 0000-0002-8281-642X
}

Purpose: The article discusses the basic differences and common features of foundations and registered associations of the NGO sector. The article analyses 8 categories concerning the characteristics of projects in foundations and registered associations in order to detect whether they differ significantly.

Design/methodology/approach: A target group was surveyed.

Findings: Based on the research, a description was compiled on the common features that were detected and differences between projects implemented in foundations and registered associations in NGO sector.

Research limitations/implications: In the article, the author collates the results of her own research on the development of projects in the NGO sector of foundations and registered associations, having full awareness that research carried out on a targeted sample does not allow generalizing conclusions for entire populations, although it allows identifying regularities present in a given community in order to outline further research directions. The research was conducted as part of the pilot project of NGOs' project management issues and is the starting point for conducting in-depth research in this area.

Practical implications: In NGOs, authorities and managers should increase their competences in project management in NGOs and promote good practices and professionalization of project management in third-sector organizations.

Social implications: The implementation of projects in foundations and registered associations is the basis of their functioning. Widespread research in this field allows increasing project awareness among NGO members.

Originality/value: A comparative project analysis was carried out for two types of NGOs: foundations and registered associations. The article is addressed to people involved in NGO project management research and to third-sector entities.

Keywords: project management, non-governmental organisations, third sector.

Category of the paper: Research paper. 


\section{Introduction}

The most common third-sector organizations in Poland are associations and foundations. According to 2018 data, there are 117,000 associations and 26,000 foundations registered in Poland. $65 \%$ of them are estimated to be active (Research Report Klon/Jawor Association, 2019a). Entities representing the NGO sector have common features that include:

- self-organization,

- formal structures,

- legal personality,

- functioning independently of public and private sector organizations,

- freedom of formation and operation,

- non-profit operation (the profits generated are transferred to the statutory activity of the organization and not distributed among the members of the organization),

- lawfulness of purpose of business,

- sovereignty and independence,

- voluntarism,

- provision of social services (goods and services). (Gliński, 2007, Yaziji, Doh, 2011, Schmidt, 2012). There are nevertheless differences between associations and foundations due to their different legal status. The main difference is that associations are defined as affiliating entities where the goal is the joint operation of their members. Foundations, on the other hand, are defined as a set of assets intended by the founder for a specific established purpose. There is no concept of membership in foundations because they are company entities. Thus, from a legal perspective, associations and foundations have different goals and assumptions (Frączak, 2011). It follows from the 2018 report, "Condition of NGOs", prepared by the Klon/Jawor Association that in reality, the activities undertaken by foundations and associations are not that much different. The reason being that both associations and foundations are achieving their goals based on projects (Research Report, Klon/Jawor Association, 2019b). Skilfully managed projects are the perfect tool to translate actions into measurable results (Marciszewska, 2019). The project is limited by budget, availability of resources and time and is a non-routine undertaking performed to meet the specific needs of the recipient (Project Management Institute, 2017). Project management is based on planning, organizing, monitoring and controlling the entire undertaking (project) and motivating people who perform it (Spałek, 2016). The area of NGO project management does not get enough recognition in Poland (Bogacz-Wojtanowska, Rymsza, 2015).

In view of the above considerations, the following research problem was formulated: What are the differences in implemented projects in foundations and registered associations of the NGO sector? In the article, the author summarizes the results of her own research on the 
development of projects in foundations and registered associations of the NGO sector. The research was conducted as part of the pilot project of NGOs' project management issues and is the starting point for conducting in-depth research in this area.

\section{Methods}

The research was conducted electronically using a survey in a target group of fifty-six NGOs operating in Poland, which had the following characteristics: they have the status of a foundation or registered association, have been operating on the market for at least a year and implement at least one project per year. Furthermore, survey respondents met the following criteria: participation in at least one project implemented in the foundation or registered association over the last 3 years and performing at least one of the roles mentioned during the implementation of the project in the foundation or registered association, such as: project manager, project team leader, member of the project team or project partner over the last 3 years. Foundations and registered associations are separate legal forms of third sector organizations. A separate analysis should be performed for these two groups to detect any differences at project level. Eight categories were selected for analysis: professional education of respondents actively operating in the surveyed organizations, use of project management methods and standards in the surveyed organizations, occurrence of project programs in the surveyed organizations, the number of projects implemented over the last 3 years by the surveyed organizations, the average duration of projects, average budget of individual projects, average number of partners in projects and average number of people comprising the project team.

\section{Results}

$63 \%$ of respondents participating in the survey represented associations (35 responses) and $37 \%$ foundations ( 21 responses). Table 1 presents the percentage distribution of certificates held from project management methods or standards or completed studies in management in individual groups of respondents. The data presented in the figure show that $51.43 \%$ of respondents representing the associations had certificates or completed studies in project management while only $14.29 \%$ of respondents representing foundations had them. 
Table 1.

Percentage distribution of certificates held in project management methods/standards or completed studies in management in the surveyed organizations.

\begin{tabular}{|c|c|c|c|c|}
\hline \multirow{2}{*}{ Item } & \multirow{2}{*}{$\begin{array}{c}\text { Surveyed } \\
\text { group }\end{array}$} & $\begin{array}{c}\text { the respondent is certified in project } \\
\text { management methods or standards } \\
\text { or has completed management } \\
\text { studies }\end{array}$ & $\begin{array}{c}\text { Responses } \\
\text { the respondent does not have a } \\
\text { certificate in project management } \\
\text { methods or standards or has not } \\
\text { completed management studies }\end{array}$ & Total \\
\hline 1. & $\begin{array}{c}\text { Registered } \\
\text { associations } \\
\mathrm{n}=35\end{array}$ & $51.43 \%$ & $48.57 \%$ & $100 \%$ \\
\hline 2. & $\begin{array}{c}\text { Foundations } \\
\mathrm{n}=21\end{array}$ & $14.29 \%$. & $85.71 \%$ & $100 \%$ \\
\hline
\end{tabular}

Source: own work.

In the surveyed associations and foundations, the percentage of applying project management methods and standards is small and is $17.14 \%$ for associations and $19.05 \%$ for foundations. The percentage distribution of the methods and project management standards used by the surveyed organizations is presented in Table 2 .

Table 2.

The percentage distribution of the methods and project management standards used by the surveyed organizations

\begin{tabular}{|c|c|c|c|c|}
\hline \multirow{2}{*}{ Item } & \multirow{2}{*}{$\begin{array}{c}\text { Surveyed } \\
\text { group }\end{array}$} & $\begin{array}{c}\text { Responses } \\
\text { the organization uses project } \\
\text { management methods and } \\
\text { standards }\end{array}$ & $\begin{array}{c}\text { the organization does not use } \\
\text { project management methods and } \\
\text { standards }\end{array}$ & Total \\
\hline 1. & $\begin{array}{c}\text { Registered } \\
\text { associations } \\
\mathrm{n}=35\end{array}$ & $17.14 \%$ & $82.86 \%$ & $100 \%$ \\
\hline 2. & $\begin{array}{c}\text { Foundations } \\
\mathrm{n}=21\end{array}$ & $19.05 \%$ & $80.95 \%$ & $100 \%$ \\
\hline
\end{tabular}

Source: own work.

The percentage distribution of project programs in the surveyed organizations is presented in Table 3 and indicates that foundations have more frequent project programs than associations. Foundation representatives declare that in their organizations project programs are used in $47.62 \%$ of cases while in associations only in $37.14 \%$ of cases.

Table 3.

Percentage distribution of project programs in the surveyed organizations

\begin{tabular}{|c|c|c|c|c|}
\hline \multirow{2}{*}{ Item } & $\begin{array}{c}\text { Surveyed } \\
\text { group }\end{array}$ & $\begin{array}{c}\text { Responses } \\
\text { there are project programs in the } \\
\text { organization }\end{array}$ & $\begin{array}{c}\text { there are no project programs in } \\
\text { the organization }\end{array}$ & Total \\
\hline 1. & $\begin{array}{c}\text { Registered } \\
\text { associations } \\
\mathrm{n}=35\end{array}$ & $37.14 \%$ & $62.86 \%$ & $100 \%$ \\
\hline 2. & $\begin{array}{c}\text { Foundations } \\
\mathrm{n}=21\end{array}$ & $47.62 \%$ & $52.38 \%$ & $100 \%$ \\
\hline
\end{tabular}

Source: own work. 
Projects were carried out in the surveyed organizations, where in the last 3 years, more than 10 projects were implemented in $60 \%$ of associations, while in foundations, more than 10 projects were implemented in only $33.33 \%$ of cases. In $25.71 \%$ of associations and in $42.86 \%$ of foundations, the number of projects implemented in the last 3 years amounted to 6 to 10 projects. In the past 3 years, 1 to 5 projects were implemented in $14.29 \%$ of associations and $23.81 \%$ of foundations. The percentage distribution of the number of implemented projects over the last 3 years is presented in Table 4 .

Table 4.

Percentage distribution of the number of projects implemented over the last 3 years in the surveyed organizations

\begin{tabular}{|c|c|c|c|c|c|}
\hline \multirow{2}{*}{ Item } & \multirow{2}{*}{$\begin{array}{c}\text { Surveyed } \\
\text { group }\end{array}$} & over 10 projects & 6 to 10 projects & 1 to 5 projects & Total \\
\cline { 3 - 6 } & $\begin{array}{c}\text { Registered } \\
\text { associations } \\
\mathrm{n}=35\end{array}$ & $60.00 \%$ & $25.71 \%$ & $14.29 \%$ & $100 \%$ \\
\hline 2. & $\begin{array}{c}\text { Foundations } \\
\mathrm{n}=21\end{array}$ & $33.33 \%$ & $42.86 \%$ & $23.81 \%$ & $100 \%$ \\
\hline
\end{tabular}

Source: own work.

In most surveyed organizations, both in associations (62.86\%) and foundations $(52.38 \%)$, the average duration of projects is up to a year. In foundations, the percentage of project duration up to one year is lower than in associations in favour of projects lasting from one to two years and above two years. Projects lasting from one to two years in foundations account for $33.33 \%$ of activities, and in associations for $25.71 \%$. Projects lasting over two years constitute a small percentage of activities in both foundations and associations and equal $14.29 \%$ and $11.43 \%$ respectively. The percentage distribution of average project duration in the surveyed organizations is presented in Table 5.

Table 5.

Percentage distribution of average project duration in the surveyed organizations

\begin{tabular}{|c|c|c|c|c|c|}
\hline Item & $\begin{array}{c}\text { Surveyed } \\
\text { group }\end{array}$ & up to a year & between 1 and 2 years & over 2 years & Total \\
\cline { 3 - 5 } & $\begin{array}{c}\text { Registered } \\
\text { associations } \\
\mathrm{n}=35\end{array}$ & $62.86 \%$ & $25.71 \%$ & $11.43 \%$ & $100 \%$ \\
\hline 2. & $\begin{array}{c}\text { Foundations } \\
\mathrm{n}=21\end{array}$ & $52.38 \%$ & $33.33 \%$ & $14.29 \%$ & $100 \%$ \\
\hline
\end{tabular}

Source: own work.

The percentage distribution of the budget of individual projects is presented in Table 6 and indicates that the budget of projects in over $70 \%$ of associations and in less than $50 \%$ of foundations was up to PLN 100,000. In 14.29\% of associations, the project budget exceeded PLN 500,000 and in the case of foundations it was 28.57\%. The budget between PLN 100,001 and 500,000 was used in $14.29 \%$ of associations and in $23.81 \%$ of foundations. 
Table 6.

Percentage distribution of individual projects budgets in the surveyed organizations

\begin{tabular}{|c|c|c|c|c|c|}
\hline \multirow{2}{*}{ Item } & $\begin{array}{c}\text { Surveyed } \\
\text { group }\end{array}$ & up to PLN 100,000 & over PLN 500,000 & $\begin{array}{c}\text { Retween PLN 100,001 } \\
\text { and 500,000 }\end{array}$ & Total \\
\cline { 3 - 6 } & $\begin{array}{c}\text { Registered } \\
\text { associations } \\
\mathrm{n}=35\end{array}$ & $71.43 \%$ & $14.29 \%$ & $14.29 \%$ & $100 \%$ \\
\hline 2. & $\begin{array}{c}\text { Foundations } \\
\mathrm{n}=21\end{array}$ & $47.62 \%$ & $28.57 \%$ & $23.81 \%$ & $100 \%$ \\
\hline
\end{tabular}

Source: own work.

In the vast majority of the surveyed group, both in associations $(88.57 \%)$ and foundations (95.24\%), projects were implemented jointly with partners. The number of partners ranged from 1 to 3 in $71.43 \%$ of cases in associations and $76.19 \%$ in foundations. $17.14 \%$ of associations and $19.05 \%$ of foundations declared more than 3 partners. Only $11.43 \%$ of projects in association and $4.76 \%$ in foundations were implemented without the support of partners. The percentage distribution of the average number of project partners in the examined organizations is presented in Table 7.

Table 7.

Percentage distribution of average number of partners in the surveyed organizations

\begin{tabular}{|c|c|c|c|c|c|}
\hline \multirow{2}{*}{ Item } & \multirow{2}{*}{$\begin{array}{l}\text { Surveyed } \\
\text { group }\end{array}$} & \multicolumn{3}{|c|}{ Responses } & \multirow{2}{*}{ Total } \\
\hline & & between 1 and 3 partners & over 3 partners & no partners & \\
\hline 1. & $\begin{array}{c}\text { Registered } \\
\text { associations } \\
\mathrm{n}=35 \\
\end{array}$ & $71.43 \%$ & $17.14 \%$ & $11.43 \%$ & $100 \%$ \\
\hline 2. & $\begin{array}{c}\text { Foundations } \\
n=21\end{array}$ & $76.19 \%$ & $19.05 \%$ & $4.76 \%$ & $100 \%$ \\
\hline
\end{tabular}

Source: own study.

Table 8 presents the percentage distribution of the average number of people in the project team in associations and foundations. It turns out that in both groups the number was between 2 and 4 people or between 5 and 10 people. In associations, such teams more often included 2 to 4 people (48.57\%) while in foundations 5 to 10 people $(47.62 \%)$. Teams of more than 10 people were very rare: $8.57 \%$ of cases in associations and $9.52 \%$ of cases in foundations.

Table 8.

Percentage distribution of the average number of people who make up the project team in the surveyed organizations

\begin{tabular}{|c|c|c|c|c|c|}
\hline \multirow{2}{*}{ Item } & $\begin{array}{c}\text { Surveyed } \\
\text { group }\end{array}$ & \multicolumn{3}{|c|}{ Responses } & \multirow{2}{*}{ Total } \\
\cline { 3 - 6 } & between 2 and 4 people & between 5 and 10 people & more than 10 people & \\
1. & $\begin{array}{c}\text { Registered } \\
\text { associations } \\
\mathrm{n}=35\end{array}$ & $48.57 \%$ & $42.86 \%$ & $8.57 \%$ & $100 \%$ \\
\hline 2. & $\begin{array}{c}\text { Foundations } \\
\mathrm{n}=21\end{array}$ & $42.86 \%$ & $47.62 \%$ & $9.52 \%$ & $100 \%$ \\
\hline
\end{tabular}

Source: own work. 


\section{Summary}

After analysing the research results it can be stated that three categories show clear differences between projects implemented in foundations and registered associations, namely, project education, number of implemented projects and project budget. The separate legal form of foundations and registered associations has little impact on implemented projects in 3 categories: the occurrence of project programs in the surveyed organizations, the size of the project team and the average duration of projects. Convergent answers were received in terms of 2 categories: the use of project management methods and standards and the number of project partners. Table 9 summarizes the project characteristics distinguished based on research.

Table 9.

A summary of research results on the characteristics of projects in the NGOs surveyed, broken down by foundations and registered associations

\begin{tabular}{|c|c|c|c|}
\hline \multirow[b]{2}{*}{ Item } & \multirow[b]{2}{*}{ Category } & \multicolumn{2}{|c|}{ Projects in NGOs } \\
\hline & & $\begin{array}{l}\text { projects implemented in } \\
\text { registered associations }\end{array}$ & $\begin{array}{c}\text { projects implemented in } \\
\text { foundations }\end{array}$ \\
\hline 1. & $\begin{array}{c}\text { Professional education } \\
\text { of respondents actively } \\
\text { operating in the } \\
\text { surveyed organizations }\end{array}$ & $\begin{array}{l}\text { Respondents implementing projects } \\
\text { in associations in over } 50 \% \text { of cases } \\
\text { hold certificates or completed } \\
\text { studies in project management. }\end{array}$ & $\begin{array}{c}\text { Respondents implementing projects } \\
\text { in associations in over } 15 \% \text { of cases } \\
\text { hold certificates or completed } \\
\text { studies in project management. }\end{array}$ \\
\hline 2. & $\begin{array}{l}\text { Application of project } \\
\text { management methods } \\
\text { and standards in the } \\
\text { surveyed organizations }\end{array}$ & $\begin{array}{c}\text { More than } 80 \% \text { of projects did not } \\
\text { use project management methods } \\
\text { and techniques available on the } \\
\text { market. }\end{array}$ & $\begin{array}{c}\text { More than } 80 \% \text { of projects did not } \\
\text { use project management methods } \\
\text { and techniques available on the } \\
\text { market. }\end{array}$ \\
\hline 3. & $\begin{array}{l}\text { Occurrence of project } \\
\text { programs in the } \\
\text { surveyed organizations }\end{array}$ & $\begin{array}{c}\text { In almost } 40 \% \text { of cases, associations } \\
\text { use project programs. }\end{array}$ & $\begin{array}{c}\text { In almost } 50 \% \text { of cases, foundations } \\
\text { use project programs. }\end{array}$ \\
\hline 4. & $\begin{array}{l}\text { Number of projects } \\
\text { implemented over the } \\
\text { last } 3 \text { years by the } \\
\text { surveyed organizations }\end{array}$ & $\begin{array}{l}\text { In the associations surveyed, } \\
\text { the largest number of respondents } \\
\text { said that over the last } 3 \text { years more } \\
\text { than } 10 \text { projects were implemented } \\
\text { in the organization. }\end{array}$ & $\begin{array}{l}\text { In the foundations surveyed, the } \\
\text { largest number of respondents said } \\
\text { that within the last } 3 \text { years, } 6 \text { to } 10 \\
\text { projects were implemented in the } \\
\text { organization. }\end{array}$ \\
\hline 5. & $\begin{array}{l}\text { Average duration of } \\
\text { projects }\end{array}$ & $\begin{array}{c}\text { The average duration of projects in } \\
\text { over } 60 \% \text { of cases was up to a year, } \\
\text { and in over } 25 \% \text { between } 1 \text { and } 2 \\
\text { years. }\end{array}$ & $\begin{array}{c}\text { The average duration of projects in } \\
\text { over } 50 \% \text { of cases was up to a year, } \\
\text { and in over } 30 \% \text { between } 1 \text { and } 2 \\
\text { years. }\end{array}$ \\
\hline 6. & $\begin{array}{l}\text { Average budget of } \\
\text { individual projects }\end{array}$ & $\begin{array}{l}\text { In over } 70 \% \text { of cases, the average } \\
\text { budget reached up to PLN 100,000. }\end{array}$ & $\begin{array}{l}\text { The average budget in less than } 50 \% \\
\text { of cases reached up to PLN } 100,000 \text {, } \\
\text { in less than } 30 \% \text { it was above } \\
\text { PLN } 500,000 \text {. }\end{array}$ \\
\hline 7. & $\begin{array}{l}\text { Average number of } \\
\text { partners in projects }\end{array}$ & $\begin{array}{l}\text { The average number of partners in } \\
\text { projects was usually from } 1 \text { to } 3 \text {. }\end{array}$ & $\begin{array}{l}\text { The average number of partners in } \\
\text { projects was usually from } 1 \text { to } 3 \text {. }\end{array}$ \\
\hline 8. & $\begin{array}{l}\text { The average number } \\
\text { of people in the project } \\
\text { team }\end{array}$ & $\begin{array}{l}\text { The project team consisted of an } \\
\text { average of } 2 \text { to } 4 \text { people or } 5 \text { to } 10 \\
\text { people, but more often the teams } \\
\text { consisted of } 2 \text { to } 4 \text { people. }\end{array}$ & $\begin{array}{l}\text { The project team consisted of } \\
\text { an average of } 2 \text { to } 4 \text { people or } 5 \text { to } \\
10 \text { people, but more often the teams } \\
\text { consisted of } 5 \text { to } 10 \text { people. }\end{array}$ \\
\hline
\end{tabular}

Source: own work. 
Definitely more people representing the surveyed associations have certificates from the methods/standards of project management or completed studies in the field of management compared to the surveyed foundations. Thus, it can be assumed that the level of knowledge about project management is higher in associations than in foundations. Over the years, associations have implemented more projects than foundations, but the duration of these projects is proportionally shorter and these projects mostly have a smaller budget and project team than the foundations surveyed. Despite the greater number of projects implemented by the associations, project programs are less frequent.

The presented research results show that the level of competence related to project management among people implementing projects is at a low level and should be raised, especially among representatives of the foundation. The low percentage of project management methods and techniques used in organizations on the market can be the result of a lack of appropriate knowledge among the people who run them. In recent years, one can observe a strong development of third sector organizations and their importance in the socio-economic system in Poland. They carry out public tasks, provide social services and cooperate with entrepreneurs (Major, Spałek, 2019). This is demonstrated by the large number of projects implemented in the surveyed organizations, the amount of their budget and the number of project partners. Project activities in third sector organizations are the basis for their functioning and development regardless of their legal form. High level of competence and project education lead to conscious implementation of assumed goals, increase of credibility among partners and effective building of project programs. The increase in competences among people who implement projects will also result in project management becoming more professional and organizations will be able to develop their own good project practices tailored to their goals and assumptions arising from the legal form they represent.

\section{References}

1. Bogacz-Wojtanowska, E., Wrona, S. (eds.) (2016). Zarzadzanie organizacjami pozarzadowymi. Monografie i Studia Instytutu Spraw Publicznych Uniwersytetu Jagiellońskiego, Kraków.

2. Frączak, P. (2011). Stowarzyszenia i inne formy zrzeszeniowe w polskim sektorze pozarządowym. Federalista, Vol. 2, pp. 32-49.

4. Major, P., Spałek, S. (2019). Zarządzanie projektami w organizacjach pozarządowych wyniki badań. Przegląd Organizacji, Vol. 3, pp. 21-26. DOI: 10.33141/po.2019.03.04.

6. Project Management Institute (2017). A Guide to the Project Management Body of Knowledge. Delaware, Pennsylvania, United States. 
7. Raport $\mathrm{z}$ badań Stowarzyszenie Klon/Jawor (2019a). Kondycja sektora organizacji pozarzadowych 2018. Warszawa. Retrieved from https://api.ngo.pl/media/get/108904, 06.06.2020.

10. Spalek, S. (2016). Traditional vs. Modern Project Management Methods. Theory and Practice. In: I. Simberova, F. Milichovsky, O. Zizlavsky (eds.), Proceedings of 21st International Scientific Conference, Economics and Management 2016 (ICEM 2016), Smart and Efficient Economy: Preparation for the Future Innovative Economy, Brno, pp. 499-506. 